\title{
Pengaruh Lingkungan Kerja Terhadap Kinerja Pegawai Pada Kantor Camat Jambi Timur Kota Jambi
}

\author{
Muhammad Emil, Erwin DS \\ Fakultas Ekonomi Universitas Batanghari \\ Correspondence email: muhammademil74@gmail.com, erwinsuganda97@gmail.com
}

\begin{abstract}
In carrying out organizational activities, the work environment is all conditions that are around workers, so that either directly or indirectly it can influence in carrying out assigned tasks. The method of collecting data in this study uses library research and field research by collecting data from a list of statements. And information that comes from books and the internet for theory making. Subdistrict Jambi Timur Kota Jambi is an arean was established on 8 November 2006 based on the regional Number 12 in 2006. Dubdistrict Jambi Timur Kota Jambi Capital City Tanjung Pinang. Based on the research results, the simple regression value is $Y=0.785+0.669 \mathrm{X}$, with an $R$ value and a $R^{2}$ value of 0.496. In the t test, the work environment affects the performance of employees at the Head Office of East Jambi, Jambi City with a tcount of 7.809 and a significant value of 0.000. Suggestions in this study are Jambi to pay attention to the work environment in the East Jambi Sub-district Office of Jambi City related to sound / noise. As employees of the sub-district office, we should pay attention to performance related to communication between colleagues.
\end{abstract}

Keywords: performance related, communication between colleagues

\section{Pendahuluan}

Sumber daya manusia merupakan hal terpenting dalam suatu organisasi baik organisasi pemerintah maupun organisasi swasta untuk mencapai tujuan atau target yang ingin dicapai. Sumber daya manusia menjadi penentu dalam tercapainya tujuan dari organisasi atau perusahaan dengan mengoptimalkan kinerja dan kontribusi secara efektif dalam kegiatan di dalam organisasi. Oleh karena itu kemajuan organisasi ditentukan pula oleh kualitas dan kapasitas sumber daya manusia yang ada di dalamnya. Manajemen sumber daya manusia merupakan bagian dari manajemen keorganisasian yang memfokuskan diri pada unsur sumber daya manusia. Manajemen sumber daya manusia mempunyai tugas dan fungsi untuk mengelola unsur kemanusiaan secara baik agar diperoleh tenaga kerja yang puas akan pekerjaannya. Manajemen sumber daya manusia dapat didefinisikan sebagai suatu perencanaan, pengorganisasian, pengarahan, pengawasan atas pengadaan, pengembangan, kompensasi, pengintegrasian, pemeliharaan, dan pemutusan hubungan kerja dengan maksud untuk mencapai tujuan organisasi perusahaan secara terpadu (Hamali, 2016).

Pada era globalisasi saat ini, setiap perusahaan di tuntut untuk memiliki manajemen yang baik. Suatu manajemen perusahaan yang baikk pasti dapat meningkatkan efektifitas sebuah perusahaan. Seperti sumber daya manusia yang merupakan salah satu faktor penting dan memiliki peran yang besar dalam suatu organisasi. Begitu pula halnya pada Kantor Camat Jambi Timur Kota Jambi yang memiliki visi dan misi yaitu Terwujudnya Pelayanan Terpadu Yang Prima Kecamatan Jambi Timur. Sumber Daya Manusia (SDM) merupakan suatu hal yang sangat penting dan harus dimiliki dalam upaya mencapai tujuan organisasi atau perusahaan. Sumber daya manusia merupakan elemen utama organisasi dibandingkan dengan elemen sumber daya yang lain seperti modal, teknologi, karena manusia itu sendiri yang mengendalikan faktor yang lain. Berikut pegawai yang ada di Kantor Kecamatan Jambi Timur, sebagai berikut:

Tabel 1

Daftar Pegawai Kantor Camat Jambi Timur tahun 2015-2019

\begin{tabular}{lcccr}
\hline No & Tahun & Jumlah Pegawai (Orang) & Perkembangan (\%) \\
\hline 1 & 2015 & & 50 & - \\
2 & 2016 & 53 & 5,7 \\
3 & 2017 & 57 & 7,0 \\
4 & 2018 & 60 & 5,0 \\
5 & 2019 & 64 & 7,1 \\
\hline
\end{tabular}

Sumber data: Laporan Pegawai Kantor Camat Jambi Timur, 2020

Tabel 1 terlihat jumlah pegawai dari tahun 2015-2019 mengalami perkembangan dari tahun ke tahun. Pada tahun 2016 sebanyak 53 mengalami perkembangan pegawai atau setara 5,7\%, tahun 2017 sebanyak 57 mengalami perkembangan pegawai atau setara 7\%, tahun 2018 sebanyak 60 mengalami perkembangan pegawai atau setara 5\%, dan tahun 2019 sebanyak 64 mengalami perkembangan pegawai atau setara 7,1\%. Hal ini sebagai akibat adanya 
peningkatan mobilisasi penduduk diwilayah camat Jambi Timur dan sekitarnya. Untuk mendukung kinerja yang kondusif maka dibutuhkan lingkungan kerja yang baik. Lingkungan kerja adalah segala sesuatu yang ada di sekitar para pekerja dan dapat mempengaruhi dirinya dalam menjalankan tugas-tugas yang di bebankan misalnya kebersihan, penerangan dan lain-lain (Sunyoto, 2013) Lingkungan kerja menyangkut wadah atau tempat dimana para pegawai menjalankan setiap tugas dan pekerjaannya. Hal ini mencakup proses penerapan manajemen dan lingkungan kerja fisik, salah satunya antara lain ruangan yang nyaman dan tertata rapi, ventilasi yang baik, keamanan kerja, jam kerja yang sesuai serta keadaan lainnya yang dapat mendukung lancarnya pelaksanaan tugas. Aspek lingkungan kerja pada dasarnya memiliki kontribusi besar terhadap jalannya operasional organisasi karena kondisi dan keadaanya mampu mengaruhi sikap pegawai yang secara langsung terhadap kinerja pegawai.

Tabel 2

Daftar Sarana dan Prasarana Pada Kantor Camat Jambi Timur Kota Jambi Tahun 2015-2019

\begin{tabular}{|c|c|c|c|c|c|c|c|c|}
\hline \multirow{2}{*}{ No } & \multirow{2}{*}{ Jenis Saran dan Prasarana Kerja } & \multicolumn{5}{|c|}{ Tahun dan Jumlah Barang } & \multicolumn{2}{|c|}{ Kondisi Barang } \\
\hline & & 2015 & 2016 & 2017 & 2018 & 2019 & Baik & Rusak \\
\hline 1 & Lemari & 5 & 5 & 5 & 5 & 5 & 4 & 1 \\
\hline 2 & Meja & 24 & 25 & 30 & 30 & 30 & 20 & 10 \\
\hline 3 & Kursi & 20 & 25 & 25 & 30 & 33 & 30 & 3 \\
\hline 4 & Komputer & 8 & 8 & 10 & 10 & 10 & 6 & 4 \\
\hline 5 & Printer & 8 & 9 & 9 & 10 & 10 & 8 & 2 \\
\hline 6 & Mesin tik & 1 & 1 & 1 & 0 & 0 & 0 & 1 \\
\hline 7 & Mobil Dinas & 2 & 2 & 2 & 2 & 2 & 2 & 0 \\
\hline 8 & Motor Dinas & 5 & 6 & 6 & 8 & 8 & 4 & 4 \\
\hline 9 & $\mathrm{AC}$ & 5 & 5 & 5 & 5 & 5 & 5 & 0 \\
\hline 10 & Papan Data & 4 & 4 & 5 & 5 & 6 & 4 & 2 \\
\hline
\end{tabular}

Sumber: Kantor Camat Jambi Timur Kota Jambi, Tahun 2020

Tabel 2 tergambar bahwa secara umum lingkungan kerja fisik pada Kantor Camat Jambi Timur cukup baik tetapi belum ideal, meskipun masih terdapat beberpa item kebutuhan peralatan kerja yang tidak dapat digunakan. Hal ini tentu saja tetap harus diperbaiki agar dapat lebih optimal dalam mendukung pekerjaan di Kantor Camat Jambi Timur Kota Jambi. Berdasarkan observasi yang peneliti lakukan di Kantor Camat Jambi Timur terdapat beberapa keadaan yang kurang kondusif, kebersihan yang kurang terjaga, kurangnya pencahayaan diruangan, fasilitas dikantor yang kurang memadai seperi printer yang banyak tidak berfungsi sehingga printer yang ada digunakan secara bersama-sama sehingga kinerja di Kantor tersebut masih rendah. Selanjutnya keamanan (security) dalam kantor hanya ada satu sehingga pegawai merasa tidak aman dalam meninggalkan dokumen-dokumen ditempat kerja, dengan lingkungan yang demikian hal ini menyebabkan tingkat kinerja juga rendah. Keberhasilan pencapaian tujuan dalam suatu organisasi tidak terlepas dari kualitas Sumber Daya Manusia yang dimiliki kualitas yang baik akan diperoleh jika organisasi secara sungguh-sungguh memperhatikan serta mengetahui kebutuhan organisasi dan kemampuan karyawannya. Kinerja yang kurang optimal dari seorang pegawai dalam melaksanakan tugas-tugas yang dibebankan kepadanya yang tidak sesuai dengan beban kerjanya dapat mengakibatkan organisasi menjadi kurang produktif dan akan dapat memunculkan ketidakpuasan dalam bekerja. Menurut Sedarmayanti (2001) kinerja adalah prestasi kerja, pelaksanaan kerja, pencapaian kerja atau hasil kerja/penampilan kerja. Kinerja merupakan hal penting yang harus diperhatikan dalam manajemen sumber daya manusia pimpinan yang sukses harus memiliki kemampuan meningkatkan produktivitas dengan harapan hasil kerja yang sesuai dengan keinginan sehingga berdampak dalam meningkatkan prestasi kerja. Oleh sebab itu diperlukan pembinaan dan pengembangan mengenai kinerja karyawan secara efektif demi terciptanya kelancaran suatu proses kegiatan dalam suatu organisasi yang akan datang. (Mangkunegara, 2011)

Tabel 3

Realisasi pencapaian Pelaksanaan Pekerjaan Pada Kantor Camat Jambi Timur Kota Jambi Tahun 2015-2019

\begin{tabular}{|c|c|c|c|}
\hline \multirow{2}{*}{ Tahun } & \multicolumn{3}{|c|}{ Pelayanan Administrasi umum } \\
\hline & Target $(\%)$ & Realisasi (\%) & Pencapaian Target (\%) \\
\hline 2015 & 85,0 & 81,7 & 96,1 \\
\hline 2016 & 87.0 & 82,0 & 94,2 \\
\hline 2017 & 87,0 & 84,6 & 97,2 \\
\hline 2018 & 90,0 & 85,1 & 94,5 \\
\hline 2019 & 90.0 & 86,0 & 95,5 \\
\hline \multicolumn{3}{|c|}{ Rata-rata } & 95,5 \\
\hline
\end{tabular}


Muhammad Emil dan Erwin DS, Pengaruh Lingkungan Kerja Terhadap Kinerja Pegawai Pada Kantor Camat Jambi Timur Kota Jambi

\begin{tabular}{|c|c|c|c|}
\hline \multirow{2}{*}{ Tahun } & \multicolumn{3}{|c|}{ Lembaga Kemasyarakatan } \\
\hline & Target $(\%)$ & Realisasi (\%) & Pencapaian Target (\%) \\
\hline 2015 & 85,0 & 75,8 & 89,1 \\
\hline 2016 & 87,0 & 80,9 & 92,9 \\
\hline 2017 & 87,0 & 79,0 & 90,8 \\
\hline 2018 & 90,0 & 80,8 & 89,8 \\
\hline 2019 & 90,0 & 81,5 & 90,5 \\
\hline \multicolumn{3}{|c|}{ Rata-rata } & 90,62 \\
\hline
\end{tabular}

\begin{tabular}{|c|c|c|c|}
\hline \multirow{2}{*}{ Tahun } & \multicolumn{3}{|c|}{ Sarana dan Prasarana Yang Dibangun } \\
\hline & Target $(\%)$ & Realisasi (\%) & Pencapaian Target $(\%)$ \\
\hline 2015 & 5 & 2,0 & 40.0 \\
\hline 2016 & 7 & 4,5 & 64,2 \\
\hline 2017 & 8 & 4,7 & 58,7 \\
\hline 2018 & 10 & 5,5 & 55.0 \\
\hline 2019 & 10 & 4,9 & 49.0 \\
\hline \multicolumn{3}{|c|}{ Rata-rata } & 53,38 \\
\hline
\end{tabular}

\begin{tabular}{|l|r|r|r|}
\hline \multirow{2}{*}{ Tahun } & \multicolumn{4}{|c|}{ Masyarakat Penerima Rastra } \\
\cline { 2 - 4 } & Target (\%) & Realisasi (\%) & Pencapaian Target (\%) \\
\hline 2015 & 2 & 1,3 & 65 \\
\hline 2016 & 2 & 1,6 & 80 \\
\hline 2017 & 2 & 1,4 & 70 \\
\hline 2018 & 2 & 1,7 & 85 \\
\hline 2019 & 2 & 1,5 & 75 \\
\hline Rata-rata & \multicolumn{3}{|c|}{} \\
\hline
\end{tabular}

Sumber: Laporan Capaian Target Kantor Camat Jambi Timur Kota Jambi (data diolah), 2020

Tabel diatas dapat dilihat bahwa kinerja pegawai pada Kantor Camat Jambi Timur Kota Jambi dalam lima tahun terakhir belum mencapai target yang maksimal yaitu $100 \%$. Pelayanan administrasi umum tepat waktu sebesar 95,5\%, Program kerja Lembaga kemasyarakatan yang aktif sebesar 90,62\%, Sarana dan prasarana public yang dibangun sebesar 53,38\%, dan Masyarakat penerima rastra (beras sejahtera) sebesar 75\%. Oleh karena itu dibutuhkan peran dari seseorang pemimpin yang harus mempunyai kemampuan untuk mengembangkan pegawai untuk dapat memberikan kontribusi yang optimal dan memiliki komitmen tinggi dan luwes dalam melaksanakan pekerjaannya.

\section{Manajemen Sumber Daya Manusia}

Menurut Sulistiyani (2018) sumber daya manusia adalah manusia yang bekerja dilingkungan suatu organisasi (disebut juga personil, tenaga kerja, pegawai atau karyawan). Sumber daya manusia (Hamali, 2016) merupakan salah satu sumber daya yang terdapat dalam organisasi, meliputi semua orang yang melakukan aktivitas. Menurut Sudaryo (2018) sumber daya manusia merupakan elemen yang paling penting/strategis dalam organisasi, sehingga harus diakuui dan diterima oleh manajemen. Sumber daya manusia adalah potensi manusiawi sebagai penggerak organisasi dalam mewujudkan eksistensinya. Sumber daya manusia adalah potensi yang merupakan asset dan berfungsi sebagai modal (non material/non finansial) di dalam organisasi bisnis, yang dapat diwujudkan menjadi potensi nyata (real) secara fisik dan non-fisik dalam mewujudkan eksistensi organisasi (Sulistiyani, 2018). Menurut Sedarmayanti (2001) manajemen sumber daya manusia adalah seni untuk merencanakan, mengorganisasikan, mengarahkan, mengawasi kegiatan sumber daya manusia atau pegawai, dalam rangka mencapai tujuan organisasi.

\section{Lingkungan Kerja}

Menurut Nitisemito (2014) lingkungan kerja adalah sesuatu yang ada disekitar para pekerja dan yang mempengaruhi dirinya dalam menjalankan tugas-tugas yang dibebankan. Menurut Bambang (2012) lingkungan kerja merupakan salah satu faktor yang mempengaruhi kinerja seorang pegawai, yang bekerja di lingkungan kerja yang mendukung dia untuk bekerja secara optimal akan menghasilkan kinerja yang baik. Sebaliknya jika seseorang pegawai bekerja dalam lingkungan kerja yang tidak memadai dan tidak mendukung untuk bekerja secara optimal akan membuat pegawai yang bersangkutan menjadi malas, cepat lelah sehingga kinerja pegawai tersebut akan rendah. Menurut Rahmawati (2014) lingkungan kerja sebagai keseluruhan sarana prasarana kerja yang ada disekitar karyawan yang sedang melaksanakan pekerjaan yang dapat mempengaruhi pekerjaan itu sendiri. Walaupun lingkungan kerja merupakan faktor penting serta dapat mempengaruhi kinerja karyawan, tetapi saat ini masih banyak perusahaan yang kurang memperhatikan kondisi lingkungan kerja disekitar perusahaannya. Sebaliknya apabila kondisi lingkungan 
kerja tersebut tidak memadai akan menimbulkan dampak negative dalam penurunan tingkat produktifitas kinerja karyawan. Menurut Sudaryo (2018) lingkungan kerja adalah lingkungan dimana pegawai melakukan pekerjaannya sehari-hari. Lingkungan kerja yang kondusif akan memberikan rasa aman dan memungkinkan para pegawai untuk dapat bekerja optimal. Selain itu, lingkungan kerja juga dapat mempengaruhi emosi pegawai.

\section{Indikator Lingkungan Kerja}

Indikator untuk menilai lingkungan kerja fisik, dapat dijelaskan sebagai berikut (Sudaryo, 2018): Penerangan/cahaya; Suhu udara; Kebersihan; Penggunaan warna/pewarnaan; Suara/kebisingan; dan Keamanan kerja

\section{Kinerja}

Kinerja menurut Hasibuan (2009) kinerja adalah suatu hasil kerja yang dicapai seseorang dalam melaksanakan tugas-tugas yang dibebankan kepadanya yang didasarkan atas kecakapan, pengalaman dan kesungguhan waktu. Kinerja adalah prestasi kerja, pelaksanaan kerja, pencapaian kerja atau hasil kerja/penampilan kerja (Sedarmayanti, 2001). Kinerja mempunyai hubungan erat dengan masalah produktivitas karena merupakan indikator dalam menentukan bagaimana usaha untuk mencapai tingkat produktivitas yang tinggi dalam suatu organisasi. Kinerja merupakan hasil pekerjaan yang mempunyai hubungan kuat dengan tujuan strategis organisasi, kepuasan konsumen, dan memberikan kontribusi pada ekonomi. Kinerja adalah tentang melakukan pekerjaan dan hasil yang dicapai dari pekerjaan tersebut (Hamali, 2016). Mathis dan Jackson (2009) mengemukakan kinerja (performance) adalah apa yang dilakukan atau tidak dilakukan oleh karyawan. Kinerja karyawan yang umum untuk kebanyakan pekerjaan meliputi elemen sebagai berikut: (a) kuantitas dari hasil, (b) Kualitas dari hasil, (c) ketepatan waktu dan hasil, (d) kehadiran dan (e) kemampuan bekerja sama. Kinerja adalah hasil dari suatu proses atau pekerjaan. Setiap karyawan dituntut untuk memiliki kompetensi yaitu kemampuan atau kecakapan melaksanakan tugas atau pekerjaan yang menjadi tanggung jawabnya atau yang dipercayakan. Setiap pelaksanaan tugas atau pekerjaan ada suatu kegiatan memproses atau mengubah input (masukan) menjadi suatu output (keluaran) yang bernilai tambah sebagai produk atau hasil kerja. Sedarmayanti (2001) menyebutkan ada 5 (lima) indikator untuk mengukur kinerja seseorang, yaitu: Kualitas Kerja (Quality of work); Ketepatan Waktu (Promptness); Inisiatif (Inisiative); Kemampuan (Capability); Komunikasi (Comunication)

\section{Metode}

Metode penelitian yang digunakan dalam penelitian ini adalah metode deskriptif dan kuantitatif. Menurut Hidayat (2010) penelitian deskriptif adalah metode penelitian yang digunakan untuk menentukan pengetahuan yang seluas-luasnya terhadap objek penelitian pada suatu masa tertentu. Penilaian kuantitatif dinamakan metode tradisional, karena metode ini sudah cukup lama digunakan sehingga sudah mentradisi sebagai metode untuk penelitian. Metode ini disebut metode ilmiah/scientific karena telah memenuhi kaidah-kaidah ilmiah yaitu konkrit/empiris, obyektif, terukur, rasional, dan sistematis (Sugiyono, 2017). Untuk menganalisis permasalahan diatas digunakan skala penelitian dengan menghitung frekuensi skor item pertanyaan. Seperti yang dikemukakan Umar (2014) bahwa perhitungan skor setiap komponen yang diteliti dengan mengalihkan seluruh frekuensi data dengan nilai bobot. Rumus yang digunakan adalah sebagai berikut:

Skor terendah : Bobot terendah $\mathrm{x}$ jumlah sampel $=1 \times 64=64$

Skor tertinggi : Bobot tertinggi $\mathrm{x}$ jumlah sampel $=5 \times 64=320$

Untuk mencari rentang skala digunakan rumus Slovin (Sugiyono, 2017) sebagai berikut:

Rentang skala $=\frac{n(m-1)}{m}=\frac{64(5-1)}{5}-51,2$

Dimana: $\mathrm{N}$ : Jumlah sampel; $\mathrm{m}$ : Jumlah alternative jawaban item berikut:

Berdasarkan jumlah rentang skala tersebut diketahui jawaban penilaian disusun dengan interval sebagai

$64-115,1=$ Sangat tidak baik/sangat rendah; 115,2 - 166,3 = Tidak Baik/Rendah; 166,4 - 217,5 = Cukup Baik/Cukup Rendah; 217,6 - 268,7 = Baik/Tinggi; 268,8 - 320 = Sangat Baik/Sangat Tinggi

\section{Regresi Linear Sederhana}

$$
\mathrm{Y}=\mathrm{a}+\mathrm{bX}+e
$$

Keterangan: $\mathrm{a}=$ Konstanta; $\mathrm{b}=$ Koefisien Regresi; $\mathrm{X}=$ Lingkungan Kerja; $\mathrm{Y}=$ Kinerja Karyawan

\section{Hasil}


Tabel 4

Rekapitulasi Jawaban Responden Terhadap 12 Item Lingkungan Kerja

\begin{tabular}{|c|c|c|c|}
\hline No & Pemyataan & Skor & Ket \\
\hline 1 & Saya merasa dalam ruangan ini terdapat pencahayaan yang cukup untuk menyelesaikan pekerjaan. & 282 & Sangat Baik \\
\hline 2 & Tempat kerja saya bekerja memiliki penerangan yang baik & 278 & Sangat Baik \\
\hline 3 & Suhu udara di ruang kerja berjalan dengan baik. & 275 & Sangat Baik \\
\hline 4 & Ventilasi di ruang kerja yang modem, membantu mempermudah setiap pekerjaan yang saya lakukan & 254 & Baik \\
\hline 5 & Tempat saya bekerja bersih dan tertata dengan baik & 274 & Sangat Baik \\
\hline 6 & Tempat kerja yang bersih membuat saya nyaman di dalam melaksanakan pekerjaan. & 264 & Sangat Baik \\
\hline 7 & Wama cat dinding yang dipakai ditempat kerja tidak mencolok & 286 & Sangat Baik \\
\hline 8 & Tempat saya bekerja memiliki pewamaan yang cerah & 270 & Sangat Baik \\
\hline 9 & Tempat kerja saya tidak terdapat suara yang mengganggu telinga. & 249 & Baik \\
\hline 10 & Tempat kerja saya jauh dari kebisingan & 271 & Sangat Baik \\
\hline 11 & Keamanan ditempat kerja sudah bekerja dengan baik. & 277 & Sangat Baik \\
\hline 12 & Saya merasa aman dalam bekerja tanpa ada rasa khawatir kehilangan barang. & 276 & Sangat Baik \\
\hline & Total & 3.256 & \\
\hline & Rata-rata & 271,3 & Sangat Baik \\
\hline
\end{tabular}

Sumber: Data diolah

Tabel 4 diketahui skor rata-rata jawaban sebesar 271,3 artinya lingkungan kerja dinilai sangat baik oleh pegawai. Jawaban pegawai tertinggi yaitu berkaitan dengan penyataan "Warna cat dinding yang dipakai ditempat kerja tidak mencolok" dengan skor sebesar 286. Jawaban pegawai terendah yaitu berkaitan dengan pernyataan "Tempat kerja saya tidak terdapat suara yang mengganggu telinga" dengan skor 249. Rekap rata-rata skor untuk masing-masing indikator lingkungan kerja pada Kantor Camat Jambi Timur Kota Jambi. Tabel 5 diketahui bahwa pegawai menempatkan indikator penggunaan warna dinilai sebagai yang tertinggi dengan rata-rata skor sebesar 282,5. Sedangkan indikator suara/kebisingan dinilai sebagai yang terendah dengan skor sebesar 260. Tabel 6 diketahui skor rata-rata jawaban sebesar 268,2 artinya kinerja pegawai dinilai tinggi oleh pegawai. Jawaban pegawai tertinggi yaitu berkaitan dengan pernyataan "Saya menyelesaikan pekerjaan tanpa meminta bantuan rekan kerja lain, tetapi tetap di awasi agar tidak terjadi kesalahan saat bekerja" dengan skor 278. Sementara jawaban pegawai terendah yaitu berkaitan dengan pernyataan "Saya dapat berkomunikasi dengan karyawan dengan baik" dengan skor 251.

Tabel 5

Hasil Jawaban Indikator Lingkungan Kerja

\begin{tabular}{|c|c|c|c|c|}
\hline No & Indikator & Pernyataan & Skor & Ket \\
\hline \multirow[t]{2}{*}{1} & \multirow{2}{*}{ Penerangan } & Saya merasa dalam ruangan ini terdapat pencahayaan yang cukup untuk menyelesaikan pekerjaan. & \multirow[t]{2}{*}{280,0} & \multirow[t]{2}{*}{ Sangat Baik } \\
\hline & & Tempat kerja saya bekerja memiliki penerangan yang baik & & \\
\hline \multirow[t]{2}{*}{2} & \multirow[t]{2}{*}{ Suhu Udara } & Suhu udara di ruang kerja berjalan dengan baik. & \multirow[t]{2}{*}{264,5} & \multirow[t]{2}{*}{ Baik } \\
\hline & & Ventilasi di ruang kerja yang modern, membantu mempermudah setiap pekerjaan yang saya lakukan & & \\
\hline \multirow[t]{2}{*}{3} & \multirow[t]{2}{*}{ Kebersihan } & Tempat saya bekerja bersih dan tertata dengan baik & \multirow[t]{2}{*}{269,0} & \multirow[t]{2}{*}{ Sangat Baik } \\
\hline & & Tempat kerja yang bersih membuat saya nyaman di dalam melaksanakan pekerjaan. & & \\
\hline \multirow[t]{2}{*}{4} & \multirow{2}{*}{$\begin{array}{l}\text { Penggunaan } \\
\text { Wama }\end{array}$} & Warna cat dinding yang dipakai ditempat kerja tidak mencolok & \multirow[t]{2}{*}{282,5} & \multirow[t]{2}{*}{ Sangat Baik } \\
\hline & & Tempat saya bekerja memiliki pewarnaan yang cerah & & \\
\hline \multirow[t]{2}{*}{5} & \multirow[t]{2}{*}{ Suara/Kebisingan } & Tempat kerja saya tidak terdapat suara yang mengganggu telinga. & \multirow[t]{2}{*}{260.0} & \multirow[t]{2}{*}{ Baik } \\
\hline & & Tempat kerja saya jauh dari kebisingan & & \\
\hline \multirow[t]{2}{*}{6} & \multirow[t]{2}{*}{ Keamanan Kerja } & Keamanan ditempat kerja sudah bekerja dengan baik. & \multirow[t]{2}{*}{276,5} & \multirow[t]{2}{*}{ Sangat Baik } \\
\hline & & Saya merasa aman dalam bekerja tanpa ada rasa khawatir kehilangan barang. & & \\
\hline
\end{tabular}

Sumber: Data diolah

Tabel 6

Rekapitulasi Jawaban Responden Terhadap 10 Item Kinerja pegawai

\begin{tabular}{|c|c|c|c|}
\hline No & Pernyataan & Skor & Ket \\
\hline 1 & Saya dapat melaksanakan pekerjaan dengan baik & 277 & Sangat Tinggi \\
\hline 2 & Saya memperhatikan keakuratan dalam penyelesaian pekerjaan. & 259 & Tinggi \\
\hline 3 & Saya dapat menyelesaikan pekerjaan secara tepat waktu dengan hasil yang memuaskan & 272 & Sangat Tinggi \\
\hline 4 & Saya dapat menyesuaikan pekerjaan sesuai dengan berat rintangan pekerjaan yang ditangani & 273 & Sangat Tinggi \\
\hline 5 & Saya menyelesaikan pekerjaan tanpa meminta bantuan rekan kerja lain, tetapi tetap di awasi agar tidak terjadi kesalahan saat bekerja & 278 & Sangat Tinggi \\
\hline 6 & Saya selalu bersifat proaktif dalam mencari berbagai sumber informasi & 271 & Sangat Tinggi \\
\hline 7 & Saya mengerjakan tugas sesuai dengan prosedur dan berusaha mencapai target yang ditetapkan perusahaan & 271 & Sangat Tinggi \\
\hline 8 & Saya mampu menyelesaikan pekerjaan yang berat dengan baik & 261 & Tinggi \\
\hline 9 & Saya dapat berkomunikasi dan bekerja sama dengan atasan dengan baik & 269 & Sangat Tinggi \\
\hline \multirow[t]{3}{*}{10} & Saya dapat berkomunikasi dengan karya wan dengan baik & 251 & Tinggi \\
\hline & Total & 2.682 & \\
\hline & Rata-rata & 268,2 & Tinggi \\
\hline
\end{tabular}

Sumber: Data diolah 
Tabel 7

Hasil Jawaban Indikator Kinerja pegawai

\begin{tabular}{|c|c|c|c|c|}
\hline No & Indikator & Pernyataan & Skor & Ket \\
\hline \multirow[t]{2}{*}{1} & \multirow{2}{*}{ Kualitas } & Saya dapat melaksanakan pekerjaan dengan baik & \multirow[t]{2}{*}{268} & \multirow{2}{*}{ Tinggi } \\
\hline & & Saya memperhatikan keakuratan dalam penyelesaian pekerjaan. & & \\
\hline \multirow[t]{2}{*}{2} & \multirow[t]{2}{*}{ Ketepatan Waktu } & Saya dapat menyelesaikan pekerjaan secara tepat waktu dengan hasil yang memuaskan & \multirow[t]{2}{*}{272,5} & \multirow{2}{*}{$\begin{array}{l}\text { Sangat } \\
\text { Tinggi }\end{array}$} \\
\hline & & Saya dapat menyesuaikan pekerjaan sesuai dengan berat rintangan pekerjaan yang ditangani & & \\
\hline \multirow[t]{2}{*}{3} & \multirow[t]{2}{*}{ Inisiatif } & Saya menyelesaikan pekerjaan tanpa meminta bantuan rekan kerja lain, tetapi tetap di awasi agar tidak terjadi kesalahan saat bekerja & \multirow[t]{2}{*}{274,5} & \multirow{2}{*}{$\begin{array}{l}\text { Sangat } \\
\text { Tinggi }\end{array}$} \\
\hline & & Saya selalu bersifat proaktif dalam mencari berbagai sumber informasi & & \\
\hline \multirow[t]{2}{*}{4} & \multirow[t]{2}{*}{ Kemampuan } & Saya mengerjakan tugas sesuai dengan prosedur dan berusaha mencapai target yang ditetapkan perusahaan & \multirow[t]{2}{*}{266} & \multirow[t]{2}{*}{ Tinggi } \\
\hline & & Saya mampu menyelesaikan pekerjaan yang berat dengan baik & & \\
\hline \multirow[t]{2}{*}{5} & \multirow[t]{2}{*}{ Komunikasi } & Saya dapat berkomunikasi dan bekerja sama dengan atasan dengan baik & \multirow[t]{2}{*}{260} & \multirow[t]{2}{*}{ Tinggi } \\
\hline & & Saya dapat berkomunikasi dengan karyawan dengan baik & & \\
\hline
\end{tabular}

Sumber: Data diolah

Tabel 7 diketahui bahwa pegawai menempatkan indikator kinerja yang terkait dengan inisiatif yang tertinggi dengan rata-rata skor sebesar 274,5. Sedangkan indikator kinerja yang terkait dengan komunikasi dinilai sebagai yang terendah dengan skor sebesar 260.

Pengaruh Lingkungan Kerja Terhadap Kinerja pegawai pada Kantor Camat Jambi Timur Kota Jambi

Tabel 8

Hasil Regresi Linier Sederhana

\begin{tabular}{|c|c|c|c|c|c|c|}
\hline \multirow{2}{*}{\multicolumn{2}{|c|}{ Model }} & \multicolumn{2}{|c|}{ Unstandardized Coefficients } & \multirow{2}{*}{$\begin{array}{c}\text { Standardized Coefficients } \\
\text { Beta }\end{array}$} & \multirow[b]{2}{*}{$\mathrm{t}$} & \multirow[b]{2}{*}{ Sig. } \\
\hline & & $\mathrm{B}$ & Std. Error & & & \\
\hline \multirow[t]{2}{*}{1} & (Constant) & .785 & .239 & & 3.288 & .002 \\
\hline & Lingkungan Kerja & .669 & .086 & .704 & 7.809 & .000 \\
\hline
\end{tabular}

Sumber: Data diolah

$\mathrm{Y}=\mathrm{a}+\mathrm{b} \cdot \mathrm{x}$

$\mathrm{Y}=0,785+0,669$

Uji regresi sederhana yaitu regresi yang hanya melibatkan dua variabel yaitu variabel lingkungan kerja dan variabel kinerja pegawai. Persamaan regresi linier tersebut dapat di interpretasikan sebagai berikut:

a. Nilai konstantanya positif sebesar 0,785 menunjukkan pengaruh positif variabel lingkungan kerja. Jika variabel lingkungan kerja naik maka variabel kinerja pegawai akan naik atau terpenuhi.

b. Nilai koefisien regresi variabel lingkungan kerja memiliki nilai positif yaitu sebesar 0,669 yang artinya semakin baik lingkungan kerja maka akan semakin positif dan baik pula kinerja pegawai di Kantor Camat Jambi Timur Kota Jambi.

Berdasarkan tabel 8, dapat diperoleh dengan nilai $t_{\text {hitung }}>\mathrm{t}_{\text {tabel }}$ yaitu 7,809 $>1,998$ dan nilai signifikan sebesar $0,000<0,05$. Maka hal ini berarti Ha diterima dengan kata lain bahwa variabel lingkungan kerja mempunyai pengaruh yang signifikan terhadap kinerja pegawai di Kantor Camat Jambi Timur Kota Jambi.

Tabel 9

Koefisien Determinasi

\begin{tabular}{|c|r|r|r|r|}
\hline Model & R & R Square & Adjusted R Square & Std. Error of the Estimate \\
\hline 1 & $.704^{\mathrm{a}}$ & .496 & .488 & .20268 \\
\hline
\end{tabular}

Sumber: Data diolah

Hasil ini menunjukkan bahwa 0,496\% atau 49,6\% menunjukkan nilai kinerja pegawai dipengaruhi oleh lingkungan kerja sedangkan sisanya sebesar 50,4\% nilai kinerja pegawai dipengaruhi atau dijelaskan oleh faktorfaktor lain yang tidak diteliti dalam penelitian ini yaitu pelatihan, motivasi, disiplin, kepemimpinan, kompensasi dan lain sebagainya.

Lingkungan kerja pada Kantor Camat Jambi Timur Kota Jambi dinilai sangat baik oleh pegawai. Hal tersebut dapat dilihat dari rata-rata nilai lingkungan kerja sebesar 271,3 jika dilihat pada rentang skala yaitu 268,8-320 artinya hipotesis mengenai lingkungan kerja dapat diterima. Dari tiga indikator yang digunakan untuk mengukur lingkungan kerja, pegawai menempatkan indikator penggunaan warna sebagai yang tertinggi dengan skor rata-rata sebesar 282,5 dan indikator suara/kebisingan yang terendah dengan skor rata-rata sebesar 260. Kinerja pegawai pada Kantor Camat Jambi Timur Kota Jambi dinilai tinggi oleh pegawai. Hal tersebut dapat dilihat dari rata-rata nilai kinerja pegawai sebesar 268,2 jika dilihat pada rentang skala yaitu 217,6-268,7 artinya hipotesis mengenai kinerja pegawai dapat diterima. Dari lima indikator yang digunakan untuk mengukur kinerja pegawai, pegawai menempatkan indikator kinerja yang terkait dengan inisiatif sebagai yang tertinggi dengan skor rata-rata sebesar 274,5 dan indikator kinerja 
yang terkait dengan komunikasi yang terendah dengan skor rata-rata sebesar 260. Hasil perhitungan dengan hasil SPSS 26 diketahui persamaan model regresi yaitu $Y=0,785+0,669$. dari persamaan tersebut terlihat bahwa adanya pengaruh positif antara lingkungan kerja terhadap kinerja pegawai pada Kantor Camat Jambi Timur Kota Jambi. Kenyataan ini dibuktikan dengan nilai koefisien regresi sebesar 0,669, artinya setiap terjadi kenaikan pada lingkungan kerja sebesar $1 \%$ maka mengakibatkan kinerja pegawai pada Kantor Camat Jambi Timur Kota Jambi mengalami peningkatan sebesar 66,9\%. Berdasarkan uji hipotesis yang dilakukan dapat dilihat bahwa lingkungan kerja berpengaruh positif terhadap kinerja pegawai. Hal ini dibuktikan dari nilai signifikan yang lebih kecil dari nilai $\alpha$ $(0,05)$ yaitu sebesar 0,000 . Hasil penelitian ini sejalan dengan penelitian Mila yang menyatakan bahwa lingkungan kerja berpengaruh terhadap kinerja pegawai. Nilai R Square sebesar 49,6\% dan sisanya sebesar 50,4\% dipengaruhi oleh variabel lain yang tidak diteliti dalam penelitian ini yaitu pelatiham motivasi, disiplin, kepemimpinan, kompensasi dan lain-lain.

\section{Simpulan}

Berdasarkan pembahasan diatas maka dapat ditarik beberapa kesimpulan sebagai berikut:

1. Lingkungan kerja pada Kantor Camat Jambi Timur Kota Jambi dinilai sangat baik dengan rata-rata nilai lingkungan kerja sebesar 271,3, dan kinerja pegawai dinilai tinggi dengan rata-rata nilai kinerja pegawai sebesar 268,2 .

2. Berdasarkan uji hipotesis bahwa lingkungan kerja berpengaruh secara signifikan terhadap kinerja pegawai di Kantor Camat Jambi Timur Kota Jambi. Hal ini di buktikan dengan nilai signifikan sebesar 0,000<0,05. Hasil koefisien determinasi sebesar 49,6\% menunjukkan nilai kinerja pegawai dipengaruhi oleh lingkungan kerja, sisanya sebesar 50,4\% nilai kinerja pegawai dipengaruhi atau dijelaskan oleh faktor-faktor lain yang tidak diteliti dalam penelitian ini.

\section{Daftar Pustaka}

Alex S. Nitisemito, 2014, Manajemen Personalia, Ghalia Indonesia, Jakarta

Bambang Wahyudi, 2012, Manajemen Sumber Daya Manusia. Sulita, Bandung

Hamali, Arif Yusuf (2016). Pemahaman Manajemen Sumber Daya Manusia Strategi Mengelola Karyawan. Yogyakarta: CAPS

Hasibuan, M. S. P. (2014). Manajemen Sumber Daya Manusia. Jakarta: PT. Bumi Aksara

Hidayat A.A., (2010). Metode Penelitian Kesehatan Paradigma Kuantitatif, Jakarta: Heath Books

Mangkunegara, A. Anwar Prabu (2011). Manajemen Sumber Daya Manusia Perusahaan. Bandung: PT. Remaja Rosda Karya

Rahmawati, Nela Pima. dkk. 2014. Pengaruh Lingkungan Kerja Terhadap Kinerja Karyawan (Studi Pada Karyawan Kantor Pelayanan Pajak Pratama Malang Utara). Jurnal Administrasi Bisnis (JAB) Vol. 8 No. 2.

Sedarmayanti (2001), Tata Kerja dan Produktivitas Kerja, Bandung: Mandar Maju

Sudaryo, Yoyo (2018), Manajemen Sumber Daya Manusia Kompensasi Tidak Langsung dan Lingkungan Kerja Fisik, Yogyakarta: Andi

Sugiyono (2017), Metode Penelitian Kuantitatif, Kualitatif, dan R\&D, Bandung: Penerbit Alfabeta.

Sulistiyani, A. T. (2018). Manajemen Sumber Daya Manusia, Yogyakarta: Gava Media

Sunyoto Danang. 2013. Manajemen Sumber Daya Manusia, CAPS (Center Of Academic Publishing Service), Yogyakarta.

Umar Husein (2014), Metode Penelitian Untuk Skripsi Dan Tesis Bisnis, PT. Raja Grafindo Persada, Jakarta. 